\title{
PENINGKATAN KEMAMPUAN LITERASI MATEMATIS SISWA SMK MELALUI MODEL GROUP INVESTIGATION DENGAN STRATEGI SCAFFOLDING
}

\author{
Rizka Siti Fazriah ${ }^{1}$, Toto $^{2}$, Ida Nuraida ${ }^{3}$ \\ 1,2,3 Program Studi Pendidikan Matematika, Univesitas Galuh, JI, RE Martadinata No. 150, Ciamis, Indonesia \\ E-mail : rizka.fazriah121@gmail.com
}

\begin{abstract}
This study aims to obtain an overview of the differences in the improvement of mathematical literacy skills of SMK students using the Group Investigation learning model with the Scaffolding strategy. This study uses quantitative research with a quasi-experimental design using The Nonequivalent Pretest-Posttest Control Group Design. The research subjects were students of class X AKL at SMK PGRI Cikoneng. The sampling technique used was the purposive sampling technique. The instrument used in this research is a test of mathematical literacy ability. The data collection method used is the test method given before and after learning (Pretest and Posttest). Data analysis using N-Gain Test, Prerequisite Test and t' Test. The results showed that there were differences in the improvement of students' mathematical literacy skills using the Group Investigation learning model with Scaffolding with the conventional model.
\end{abstract}

Keywords: Model Group Investigation, Scaffolding Strategy, Mathematical Literacy Ability

\begin{abstract}
ABSTRAK
Penelitian ini bertujuan untuk memperoleh gambaran mengenai perbedaan peningkatan kemampuan literasi matematis siswa SMK menggunakan model pembelajaran Group Investigation dengan strategi Scaffolding. Penelitian ini menggunakan penelitian kuantitatif dengan design Quasi eksperiment dengan menggunakan The Nonequivalent Pretest-Posttest Control Group Design. Subjek penelitiannya adalah siswa kelas X AKL di SMK PGRI Cikoneng. Teknik pengambilan sampel menggunakan teknik Purposive Sampling. Instrumen yang digunakan dalam penelitian ini adalah tes kemampuan literasi matematis. Metode pengumpulan data yang digunakan adalah metode tes yang diberikan sebelum dan setelah pembelajaran (Pretest dan Postest). Data analisis menggunakan Uji N-Gain, Uji Prasyarat dan Uji t'. Hasil penelitian menunjukan adanya perbedaan peningkatan kemampuan literasi matematis siswa yang menggunakan model pembelajaran Group Investigation dengan Scaffolding dengan model konvensional.
\end{abstract}

Kata Kunci: Model Group Investigation, Strategi Scaffolding, Kemampuan Literasi Matematis

Cara Sitasi : Fazriah, R., S.,Toto., \& Nuraida, I. (2021). Penerapan Model Group Investigation (GI) dengan Stategi Scaffolding Dalam Meningkatkan Kemampuan Literasi Matematis Siswa SMK. J-KIP (Jurnal Keguruan dan IImu Pendidikan), 2(3), 125-130. 


\section{PENDAHULUAN}

Pendidikan merupakan peranan penting dalam mempersiapkan perkembangan ilmu pengetahuan. Pendidikan merupakan hal penting dalam rangka meningkatkan kualitas Sumber Daya Manusia baik dari segi spiritual, intelegensi, maupun skill untuk menunjang kehidupannya (Sopiah et al., 2020). Melalui pendidikan diharapkan dapat mencetak individu yang kreatif dan inovatif.

Pembelajaran Matematika bisa mempersiapkan siswa sanggup menghadapi perubahan di dalam kehidupan dan di dunia yang selalu berkembang. Matematika sering dianggap sulit oleh siswa, dikarenakan tingkat berfikir siswa memiliki hambatan saat menghadapi soal matematika. Tasyanti (2018) mengemukakan untuk mengatasi permasalahan berpikir matematis tingkat tinggi pada siswa, harus dipilih model pembelajaran yang tepat agar siswa mampu memecahkan masalah sehingga dapat mengkomunikasikannya dengan baik. Dalam menggunakan strategi dan metode pembelajaran yang bervariasi akan membuat ketertarikan peserta didik meningkat dalam proses pembelajaran.

Pembelajaran matematika tidak hanya ditujukan kemampuan berhitung. Pembelajaran Matematika ada lima keamampuan matematis. kelima kemampuan yakni penalaran matematis, representasi matematis, koneksi matematis, komunikasi matematis dan pemecahan masalah matematis.

Amalia (2017) mengemukakan Group Investigasi (GI) merupakan salah satu cara untuk meningkatkan kemampuan siswa dalam berpikir dan bernalar. Dalam model pembelajaran group investigation siswa dapat bekerjasama untuk menyelesaikan masalah dalam mengatasi pola pikir yang berbeda. Siswa bertanggung jawab atas penguasaan materi belajar yang ditugaskan lalu mengajarkan bagian tersebut pada anggota yang lain. Strategi scaffolding mampu mendorong siswa agar dapat belajar secara mandiri.

Buyung \& Dwijanto (2017) mengemukakan bahwa keberhasilan siswa di Indonesia selama ini banyak dinilai masyarakat dari sisi dalam negeri saja, misalnya keberhasilan siswa dalam menghadapi ujian nasional yang masih menjadi standar penilaian pendidikan oleh masyarakat awam, namun sebenarnya pendidikan tidak dapat dinilai maupun dipandang dari ruang lingkup yang sempit. Sebab masih kurangnya siswa di Indonesia menyelesaikan masalah yang berkaitan dengan kehidupan sehari-hari. Hal ini terlihat pada rendahnya nilai matematika Indonesia dalam studi komparatif internasional PISA (Programme for International Student Assesment).

Zyngier (Fatwa et al., 2013) mengemukakan Literasi matematis didefinisikan sebagai kemampuan seseorang individu merumuskan, menggunakan dan menafsirkan matematika dalam berbagai konteks, termasuk kemampuan melakukan penalaran secara matematis dan menggunakan konsep, prosedur, fakta, sebagai alat untuk mendeskripsikan, menerangkan dan memprediksi suatu fenomena atau kejadian.

Kemampuan literasi matematis dapat membuat siswa mengenal fungsi matematika dalam kehidupan, dan sebagai dasar pertimbangan untuk membuat keputusan yang dibutuhkan oleh masyarakat. Kemampuan literasi matematis sejatinya sangat dibutuhkan individu terutama bagi siswa lulusan SMK untuk bersaing dalam pesatnya kemajuan dan perkembangan teknologi seperti sekarang ini. Siswa SMK masih banyak yang mengalami kesulitan dalam pembelajaran matematika, salah satunya siswa seringkali merasa kesulitan saat memahami materi, sehingga menyebabkan kurangnya kemampuan literasi matematis.

Hal ini diperkuat ketika peneliti melakukan observasi pada sebuah SMK di Ciamis dan hasil observasi menunjukan bahwa siswa cenderung bosan ketika melaksanakan 
pembelajaran yang tidak bervariatif, keaktifan siswa menurun, tentunya kemampuan matematis siswa sulit dicapai.

Berdasarkan latar belakang di atas maka, penelitian ini mengambil judul "Penerapan model Group Investigation dengan strategi Scaffolding dalam Meningkatkan Kemampuan Literasi Matematis Siswa SMK".

Penelitian ini bertujuan untuk mengetahui perbedaan peningkatan literasi matematis siswa SMK dengan model Group Investigation dengan strategi Scaffolding.

\section{METODE PENELITIAN}

Penelitian ini adalah penelitian Kuantitatif quasi Experiment dengan desain The Nonequivalent Pretest Postest Control Group Design. Populasi dari penelitian ini adalah seluruh siswa kelas X SMK PGRI Cikoneng Semester Genap tahun ajaran 2020/2021. Teknik pengambilan sampel dilakukan dengan menggunakan teknik Purposive Sampling. Instrumen yang digunakan dalam penelitian ini adalah tes kemampuan literasi matematis. Metode pengumpulan data yang digunakan adalah metode tes yang diberikan sebelum dan setelah pembelajaran (Pretest dan Postest). Data analisis menggunakan uji N-Gain, uji Prasyarat (Uji Normalitas dan Uji Homogenitas) dan Ujit.

\section{HASIL DAN PEMBAHASAN}

Penelitian ini dilaksanakan pada Semester Genap Tahun Ajaran 2020/2021 pada Bulan April - Mei 2021.Penelitian dilaksanakan di SMK PGRI Cikoneng yang beralamat di Jalan Raya Cikoneng No. 144 Kecamatan Cikoneng Kabupaten Ciamis. Penelitian dilaksanakan dengan menyusun jam pelajaran matematika kelas $\mathrm{X}$ yang digunakan sebagai sampel penelitian.

Berdasarkan hasil penelitian berupa nilai pretest dan posttest. Data awal berupa pretest dan posttest diubah menjadi data N-Gain untuk digunakan sebagai uji prasyarat analisis (uji Normalitas dan Uji Homogenitas), yang selanjutnya dilakukan uji hipotesis. Adapun rata-rata pretest, rata-rata posttest dan rata-rata N-Gain dapat dilihat pada Tabel 1.

Tabel 1. Rata-rata Pretest, Postest dan N-Gain

\begin{tabular}{cccc}
\hline Kelas & Pretest & $\begin{array}{c}\text { Rata-rata } \\
\text { Postest }\end{array}$ & N-Gain \\
\hline Group Investigation dengan & 6,47 & 8,72 & 0,63 \\
Scaffolding & 5,51 & 8,02 & 0,52 \\
Konvensional & & & \\
\hline
\end{tabular}

Tabel 1 menunjukkan bahwa adanya peningkatan kemampuan literasi matematis siswa. Pada Tabel 1 dapat kita lihat bahwa untuk rata-rata hasil pretest adalah 6,47 kemudian peneliti melakukan penelitian dengan model pembelajaran Group Investigation dengan strategi Scaffolding dan hasil rata-rata Postest menunjukkan nilai rata-rata adalah 8,72 artinya adanya peningkatan kemampuan literasi matematis.

Dasar kemampuan penilaian literasi matematis yang diambil peneliti sesuai dengan yang dikemukakan oleh OECD (Buyung \& Dwijanto, 2017) mengemukakan bahwa:

1. Merumuskan soal ke bentuk matematika

2. Menerapkan konsep matematika, fakta, prosedur dan penalaran,

3. Menafsirkan, dan mengevaluasi hasil yang diperoleh. 
Penerapan model pembelajaran Group Investigation dengan strategi Scaffolding pada setiap indikator kamampuan literasi matematis siswa dapat dilihat pada Gambar 1.

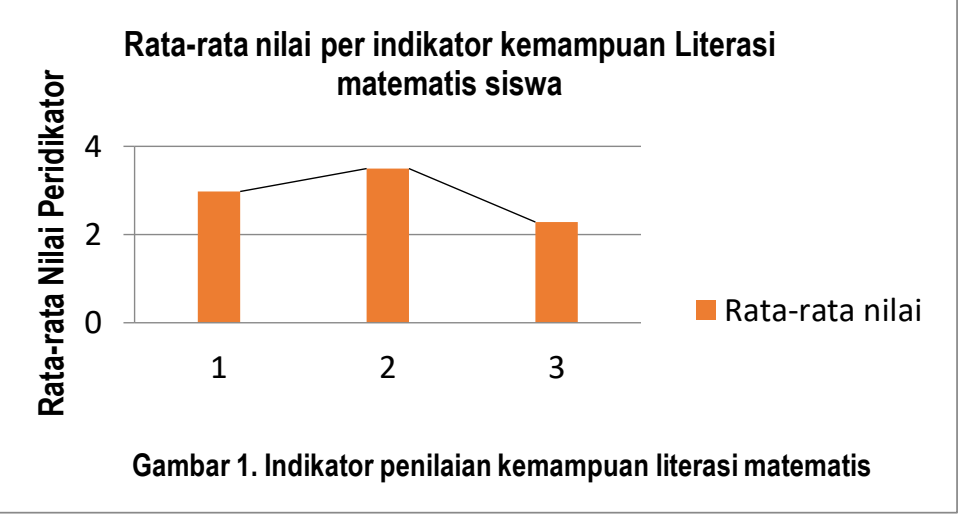

Gambar 1 menunjukan rata-rata nilai kemampuan litarasi matematis pada setiap indikator yang menjadi dasar penilaian kemampuan literasi.

Untuk mengetahui hipotesis diterima atau tidak dilakukan uji statistik. Data N-Gain dilakukan uji Normalitas dan uji Homogenitas. Setelah data berdistribusi normal dan homogen selanjutnya dilakukan uji hipotesis yakni uji t' dua sampel independen.

Tabel 2. Hasil Analisis Data Kemampuan Literasi Matematis

\begin{tabular}{|c|c|c|}
\hline \multicolumn{2}{|c|}{ Teknik Analisis } & \multirow[t]{2}{*}{ Keterangan } \\
\hline Uji Normalitas & & \\
\hline $\begin{array}{l}\text { - Kelas Konvensional } \\
\text { - Kelas Group }\end{array}$ & Sig. $=0,063$ & 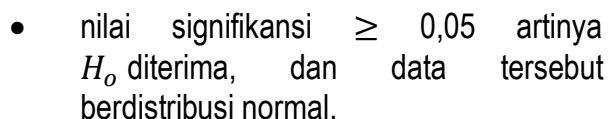 \\
\hline $\begin{array}{l}\text { Investigation dengan } \\
\text { Scaffolding }\end{array}$ & Sig. $=0,088$ & $\begin{array}{l}\text { - } \begin{array}{l}\text { nilai signifikansi } \geq 0,05 \text { artinya } \\
H_{o} \text { diterima, dan } \\
\text { berdistribusi normal }\end{array} \text { data tersebut }\end{array}$ \\
\hline Uji Homogenitas & Sig. $=0,200$ & $\begin{array}{l}\text { nilai signifikansi }<0,05 \text { artinya } H_{o} \text { ditolak, } \\
\text { berarti varians untuk kedua kelas tidak } \\
\text { homogen. }\end{array}$ \\
\hline Uji Hipotesis & $\begin{array}{l}\text { Sig. }(2-\text { Tailed })= \\
0,049\end{array}$ & $\begin{array}{l}\text { Nilai signifikansi }<0,05 \text { artinya } H_{o} \text { ditolak, } \\
\text { berarti terdapat perbedaan peningkatan } \\
\text { kemampuan literasi matematis siswa yang } \\
\text { memperoleh model pembelajaran Group } \\
\text { Investigation dengan Scaffolding dengan } \\
\text { Model pembelajaran Konvensional }\end{array}$ \\
\hline
\end{tabular}

Dari hasil Tabel 2 menunjukkan bahwa dari kedua data nilai signifikansi $\geq 0,05$ artinya data tersebut berdistribusi normal. Diperoleh data nilai signifikansi $<0,05$ artinya varians untuk kedua kelas tidak homogen. Karena data berdistribusi normal dan tidak homogen maka uji hipotesis menggunakan uji t' dua sampel independen. Hasil uji t' dua sampel independen menujukan bahwa nilai signifikansi $<0,05$ artinya terdapat perbedaan peningkatan kemampuan literasi matematis siswa yang memperoleh model pembelajaran Group Investigation dengan Scaffolding dengan Model pembelajaran Konvensional.

Hasil penelitian menunujukan bahwa penerapan model Group Investigation dengan strategi Scaffolding mampu meningkatkan kemampuan literasi matematis siswa. Pembelajaran kooperatif tipe Group Investigation dikatakan berkualitas (Tasyanti, 2018).

Berdasarkan rata-rata hasil pretest dan posttest terlihat adanya peningkatan nilai kemampuan literasi matematis siswa. Nilai rata-rata posttest cenderung lebih meningkat 
setelah dilakukannya treatment menggunakan model Group Investigation dengan Strategi Scaffolding.

Untuk melihat hasil peningkatan kemampuan literasi matematis siswa dilihat dari rata-rata hasil uji $\mathrm{N}$-Gain kita dapat lihat pada tabel 1 yang menunjukan nilai rata-rata $\mathrm{N}$ Gain adalah 0,63 ini artinya adanya peningkatan pada nilai kemampuan siswa sebelum dan sesudah dilakukan treatment dengan kriteria sedang. Setelah kita ketahui bahwa terdapatnya peningkatan kemampuan literasi matematis siswa sebelum dan sesudah diberikannya pemberlakuan dengan ini peneliti ingin meneliti perbedaan tingkat kemampuan literasi matematis siswa ketika diberikan model pembelajaran Group Investigation dengan Strategi Scaffolding dengan siswa yang mendapatkan model pembelajaran konvensional maka, dilakukannya uji t' dua sampel independent dan hasil uji t' menunjukkan bahwa adanya perbedaan peningkatan kemampuan literasi matematis siswa ketika menggunakan model Group Investigation dengan Strategi Scaffolding dengan siswa yang menggunakan model pembelajaran konvensional.

\section{KESIMPULAN}

Setelah melakukan penelitian dan analisis data hasil penelitian dapat disimpulkan bahwa terdapat perbedaan peningkatan kemampuan literasi matematis siswa ketika menggunakan model pembelajaran Group Investigation dengan strategi Scaffolding dengan siswa yang menggunakan model pembelajaran konvensional.

\section{REKOMENDASI}

Merujuk pada kesimpulan yang dipaparkan maka didapatkan saran atau rekomendasi siswa diharapkan lebih aktif dalam pembelajaran Group Investigation dan focus, guru diharapkan menjadi motivator dan fasilitator juga mengupayakan dalam strategi pembelajaran matematika, ketika belajar secara kelompok perlu adanya tempat yang memadai sehingga siswa akan konsentrasi pada proses pembelajaran.

\section{UCAPAN TERIMA KASIH}

Penulis menyampaikan terima kasih kepada semua pihak yang telah memberikan dukungansehingga artikel ini dapat diselesaikan.

\section{DAFTAR PUSTAKA}

Amalia, F. (2017) Meningkatkan Kemampuan Penalaran Matematika Materi Sistem Persamaan Linear Dua Variabel Menggunakan Model Pembelajaran Kumon dan Group Investigation pada Siswa Kelas X. Retrieved form : fitaamalia1993@gmail.com

Buyung \& Dwijanto. (2017). Analisis Kemampuan Literasi Matematis melalui Pembelajaran Inkuiri dengan Strategi Scaffolding. UJMER, 6(1), 112-119. Retrieved form : 21.buyung@gmail.com.

Fatwa, C. V., Septian, A., \& Inayah, S. (2019). Kemampuan Literasi Matematis Siswa melalui Model Pembelajaran Problem Based Instruction. Mosharafa :Jurnal Pendidikan Matematika. 8. Retrieved form : vikaconie@gmail.com, ariseptian@unsur.ac.id, inayahsarah@unsur.ac.id.

Sopiah, E, S., Effendi, A., \& Sunaryo, Y. (2020). Analisis Kemampuan Berpikir Kreatif Matematis Siswa Kelas VIII pada Materi Sistem Persamaan Linear Dua Variabel 
(SPLDV). J-KIP (Jurnal Keguruan dan IImu Pendidikan), 1 (2), 1-10.

Tasyanti, T. (2018). Analisis Kemampuan Literasi Matematika Berdasarkan Kecerdasan Emosional Siswa melalui Model Pembelajaran Kooperatif Tipe Group Investigation. Prisma, Prosiding Seminar Nasional Matematika. 1, 334-346. Retrieved form : tritasyanti@gmail.com 